\title{
The Relationship between Institutional Environments and Entrepreneurial Intention in Estonia: Mediating Roles of Desirability and Feasibility
}

\author{
Wisuwat Wannamakok, Yu-Yu Chang, Marge Täks
}

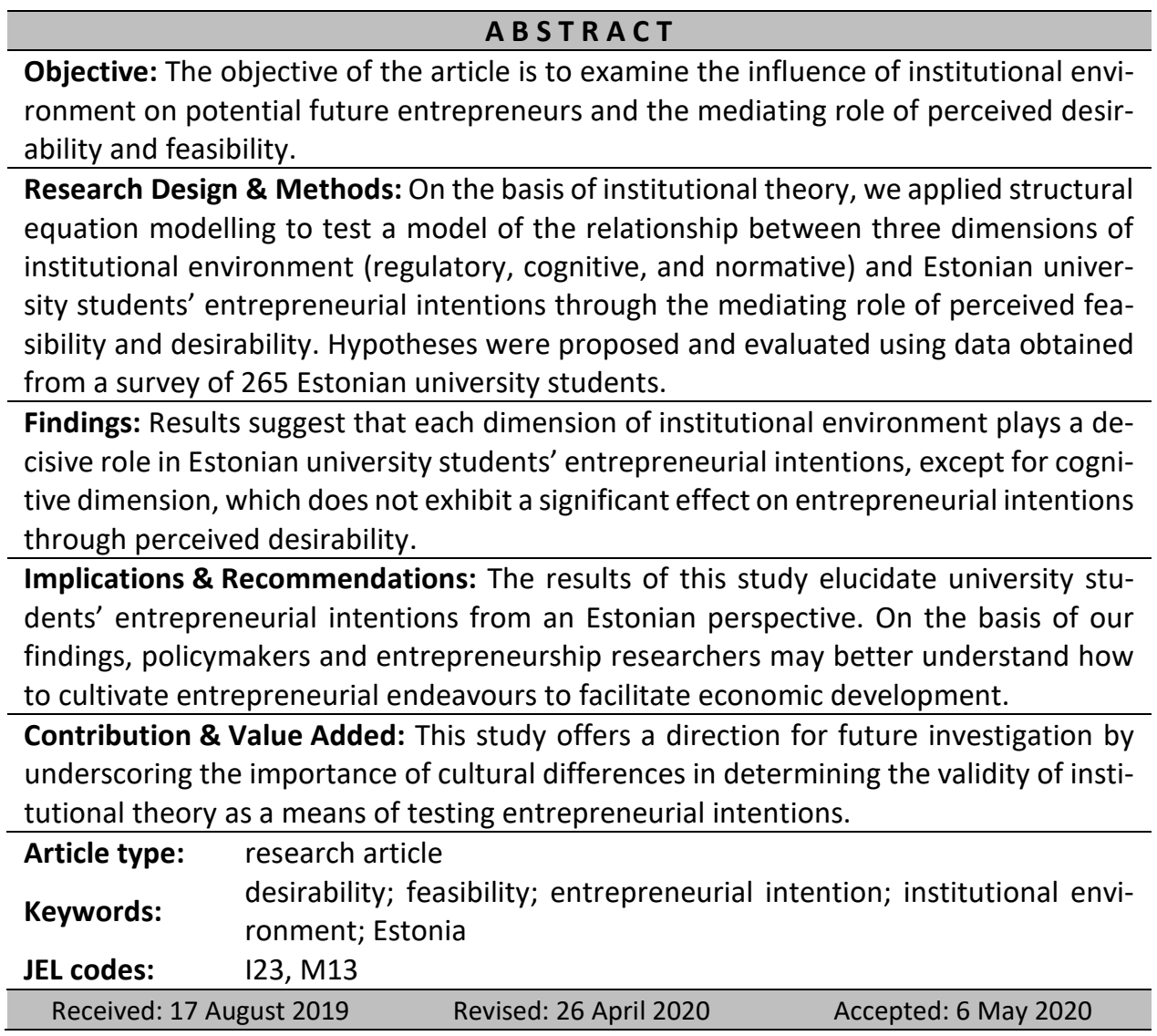

\section{Suggested citation:}

Wannamakok, W., Chang, Y.Y., \& Täks, M. (2020). The Relationship between Institutional Environments and Entrepreneurial Intention in Estonia: Mediating Roles of Desirability and Feasibility. Entrepreneurial Business and Economics Review, 8(2), 111-126. https://doi.org/10.15678/EBER.2020.080206 


\section{INTRODUCTION}

Unemployment is a major challenge in EU countries such as Estonia (Michoń, 2019; Mursa et al., 2018; Organisation for Economic Co-operation and Development, 2018). Unemployment has been an economic reality since the beginning of the global financial crisis in 2008, and it affects the welfare and happiness of the Estonian society. Because of the economic recession, people are forced to adapt to dynamic situations for survival. Nevertheless, the highly uncertain market resulting from economic crises also offers many hidden opportunities that may lead to entrepreneurial business ideas (Melin, 2002). Consequently, according to reports of the Small Business Act Europe (SBA, 2017, 2018), early-stage entrepreneurial activity in Estonia has substantially increased and has been the highest in the European Union since 2014. Moreover, the Estonian government also continues to support entrepreneurial activities. Therefore, Estonia has the third-highest established business ownership rate in the European Union, which increased from 5.0\% in 2013 to $11.4 \%$ in 2017 (SBA, 2018). Besides, the Estonian government has endeavoured to forge a favourable environment for entrepreneurs. As revealed by the World Bank, Estonia ranked 12th out of 190 countries for the ease of starting and running a business (SBA, 2018). Furthermore, Estonian entrepreneurs constitute the backbone of the start-up ecosystem, and their new venture initiatives consistently boost the country's economy. At the beginning of 2017, approximately 450 start-ups were founded in Estonia (SBA, 2018).

Franco and Haase (2019) indicate the importance of entrepreneurship to job creation and economic growth in a country. Moreover, the disruptive changes engendered by startup firms may rejuvenate a stagnant economy, substantially increasing the competitiveness of a region, state, or country (Murphy \& Dyrenfurth, 2019). Thus, in highly uncertain and volatile situations, many governments worldwide devote considerable efforts to nurturing entrepreneurship so as to reap the economic benefits that accompany new venture activities (Busenitz, Gomez, \& Spencer, 2000; Urban \& Kujinga, 2017). For example, the United States of America and several European countries have attempted to develop industrial ecosystems that facilitate open innovation and knowledge exchange among university, industry, and research institutes to ultimately contribute to the establishment of entrepreneurial companies (Díaz-Casero et al., 2009).

To ensure continued economic growth, policymakers should embrace an entrepreneurial mindset by providing a more supportive institutional environment for innovative activities that stimulate individuals' enterprising spirit (Busenitz et al., 2000; Ferreira, Hernández, \& Barata, 2009; Urban \& Kujinga, 2017). Entrepreneurship has been the backbone of technology advancement and the evolution of existing industries. As a Baltic nation, Estonia has long been recognised as a proactive market with well-established advanced information and communications technology and network infrastructures. Furthermore, the government's exploratory attitude towards radical industrial development has rendered the nation an ideal venue for pioneering projects and entrepreneurial businesses (Dutta, Geiger, \& Lanvin, 2015). Although a growing body of research has explored individuals' entrepreneurial motivations, little is known about people's intentions to start a new venture from an Eastern European or a Baltic perspective (Shneor, Jenssen, \& Vissak, 2016).

Research has extensively adopted the lens of institutional theory to understand why people from various countries differ in their entrepreneurial intentions and behaviours 
(Busenitz et al., 2000; Urban \& Kujinga, 2017). A country's institutional environment is embodied in three major dimensions: regulatory, cognitive, and normative institutions (Busenitz et al., 2000; Scott, 1995). Empirical research demonstrated that the three institutional dimensions considerably shape individuals' entrepreneurship and their intentions to start a business by regulating their perceptions of new venture creation processes (Ahlstrom \& Bruton, 2010; Heilbrunn, Itzkovitch, \& Weinberg, 2017; Manolova, Eunni, \& Gyoshev, 2008). From the intentionality perspective, perceptions that determine individuals' entrepreneurial intention include perceived feasibility and desirability towards entrepreneurial activities (Ajzen, 1991; Bruno \& Tyebjee, 1982; Shapero \& Sokol, 1982). When individuals have positive perceptions of an enterprising career and their self-efficacy in running a startup firm, they are more likely to have the propensity to act (Heilbrunn et al., 2017).

To obtain a clearer understanding of individuals' entrepreneurship in a Baltic context, this study investigated Estonian university students' new venture intentions by adopting institutional theory and the intentionality perspective of entrepreneurship. Specifically, we explored how the institutional environment affects Estonian students' entrepreneurial intentions through perceived desirability and feasibility. The findings of this study provide implications for policymakers and elucidate directions for future research on entrepreneurship. The paper is organised according to the following. The next section addresses the development of literature and hypotheses. We then describe the research design, process of data collection, and the analytic approach. The following section illustrates the findings. Lastly, we include summary of our results and their implications.

\section{LITERATURE REVIEW}

According to Whitley (1999), institutional theory explains how and why countries perform differently in economic activities. Entrepreneurship has been the driving force behind economic growth and social development. To understand people's enterprising spirit, studies have often adopted the view of institutional theory to explore the origin and motivation of new venture creation (Ahlstrom \& Bruton, 2010; Jennings et al., 2013). Accordingly, the Estonian government formulated its 2014-2020 Estonian entrepreneurship growth strategy, which prioritises entrepreneurship and start-ups. The goals of this strategy include establishing training programmes for new businesses, attracting foreign investors to Estonia, and accelerating early-stage capital within the country (SBA, 2018). The government plays a key role in spurring the entrepreneurship sphere in the country. Minniti (2008) also establish that government actions and policies can influence entrepreneurship in the country. Brush et al. (2003) and Katz (2003) confirm as well that entrepreneurship-friendly institutional infrastructure and government actions and policies can influence the desire to promote entrepreneurship and innovation, which in many countries reduce unemployment. Thus, factors related to institutional environments cannot be ignored and should be considered as crucial determinants in the measurement of entrepreneurial intentions at the country level. On the basis of the concepts presented by Scott (1995) and Busenitz et al. (2000), we divided institutional environment determinants into three dimensions: regulatory, cognitive, and normative. These dimensions are explained as follows.

Firstly, the regulatory environment dimension reflects a codified set of laws, legislation, and government policies formally designed to implement a country's entrepre- 
neurial activity support system. The desire to become an entrepreneur depends on factors such as the legal system in the country and the global economic situation (Shane, Locke, \& Collins, 2003). According to Busenitz et al. (2000), the regulatory environment dictates the degree to which entrepreneurial innovation and creative thinking are appreciated by a country's residents. Secondly, the cognitive environment dimension refers to peoples' beliefs, skills, and knowledge with regard to founding new businesses. This dimension includes beliefs about the expected persistence of a particular behaviour that is specific to a culture, community, and society. Therefore, according to Busenitz et al. (2000), the ability of people in a country to recognise the cognitive dimension can reflect their knowledge and skills to establish and operate a new business. Accordingly, the perspective of entrepreneurial cognition can be employed to understand how and why entrepreneurs think and act as they do (Krueger, Reilly, \& Carsrud, 2000). Thirdly, the normative environment dimension includes the predominant sets of standards and norms supporting entrepreneurial action in the country (Scott, 2007). In line with the findings of Veciana, Aponte, and Urban (2002), cultural, social, political, and economic factors are powerful predictors of entrepreneurial intention. In summary, all three institutional environment dimensions are powerful factors that shape a country's entrepreneurship (Ahlstrom \& Bruton, 2010; Manolova et al., 2008). Notably, the favourable environment or societal legitimisation perspective suggests that individuals' prevailing beliefs and values might make them more inclined towards new venture creation, which seems to vary among countries (Vaillant \& Lafuente, 2007).

On the basis of the theory of planned behaviour, perceived desirability and feasibility have been important factors that explain or predict entrepreneurial intention. Dodd, Dodd, Komselis, and Hassid (2009) argue that entrepreneurial intention can also be determined by other factors. For example, according to the concept of moral obligation described by Ajzen (1991), perceptions of social obligation might influence or determine an individual's intention to adhere to certain social behaviours. That is, if individuals believe that other people will engage in a behaviour in their immediate environment, they will experience a greater desire to engage in that behaviour. Similarly, according to Fayolle and Francisco (2014) and Shane (2008), individuals' perceptions of desirability and feasibility are influenced by regulatory, normative, and cognitive institutional environments. Thus, from the perspective of institutional environments, entrepreneurial intention can be described as the willingness to create new ventures that is determined by individuals' perceived feasibility and desirability (Krueger et al., 2000). Perceived desirability refers to the degree to which people identify the prospect of pursuing their own new venture as desirable (Dodd et al., 2009). On the basis of perceived desirability, people may doubt whether they want to have their own venture. This is consistent with Shane's (2003) observation that normative and cognitive foundations influence the level of individuals' entrepreneurial desirability. Therefore, we propose the following hypotheses:

H1a: A regulatory institutional environment is positively related to entrepreneurial intentions through perceived desirability.

H1b: A cognitive institutional environment is positively related to entrepreneurial intentions through perceived desirability.

H1c: A normative institutional environment is positively related to entrepreneurial intentions through perceived desirability. 
Similarly, perceived feasibility refers to the degree to which individuals believe that they are capable of becoming entrepreneurs. This can be measured by perceptions of business success, levels of self-efficacy, and knowledge about new businesses (Krueger \& Brazeal, 1994). In accordance with institutional theory, several scholars have found that the regulatory institutional environment affects perceived feasibility and new venture creation (Heilbrunn et al., 2017; Urban, 2013). Researchers have suggested that the regulatory environment should be included in a broader framework for entrepreneurship (e.g. Bernardino, Santos, \& Ribeiro, 2016). Moreover, behavioural and cognitive aspects are linked with entrepreneurial intention (Urban, 2008). Therefore, the cognitive dimension can also boost people's self-belief, through which they eventually perceive their capability of performing actions with the feasible entrepreneurial perspective (Shane, 2008). Thus, institutional environment determinants can influence people's perceptions of the feasibility of entrepreneurial processes. Therefore, feasibility is a crucial predictor of entrepreneurial intentions. Accordingly, we propose the following hypotheses:

H2a: A regulatory institutional environment is positively related to entrepreneurial intentions through perceived feasibility.

H2b: A cognitive institutional environment is positively related to entrepreneurial intentions through perceived feasibility.

H2c: A normative institutional environment is positively related to entrepreneurial intentions through perceived feasibility.

According to Ajzen's (1991) theory, perceived desirability and feasibility can be considered powerful predictors of new venture formation. Similarly, Krueger et al. (2000) observe a positive influence of desirability and feasibility on entrepreneurial intentions. Therefore, to be an entrepreneur, a person must perceive themselves as capable of entrepreneurial actions. Specifically, individuals' perceived feasibility and desirability can lead to entrepreneurial activity in a country. Accordingly, this study could contribute to the literature on entrepreneurial intention. Thus, we propose the following hypotheses:

H3: Perceived feasibility is positively related to entrepreneurial intention.

H4: Perceived desirability is positively related to entrepreneurial intention.

\section{MATERIAL AND METHODS}

On the basis of the literature review (Ajzen, 1991; Busenitz et al., 2000), we developed and tested a structural model. The model explains the relationship between institutional environment and Estonian students' entrepreneurial intention under the mediating role of perceived desirability and feasibility. Figure 1 illustrates the theoretical framework.

\section{Data Collection}

Measurement items were initially developed in English and then translated into the Estonian language by an Estonian professor of management. The questionnaire was sent online to Estonian universities. All items were rated on a five-point Likert scale. After incomplete data were excluded, the sample comprised 265 valid responses. Because universities are considered the source of the future workforce, the use of students as research sample to investigate career aspiration and entrepreneurial intentions is a common approach in the literature 
(e.g. Entrialgo \& Iglesias, 2016; Lourenço, Sappleton, \& Cheng, 2015). The Global Entrepreneurship Monitor Report also suggested that the young people who study at universities are potential candidates for entrepreneurs in the near future (GEM, 2015).

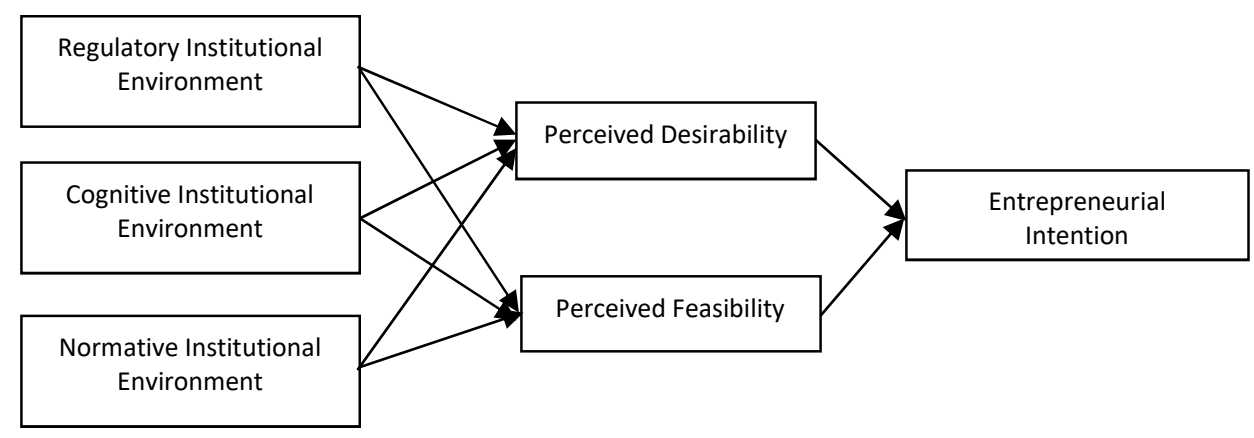

Figure 1. Theoretical Framework

Source: adapted from Ajzen (1991) and Busenitz et al. (2000).

In this study, the institutional environment determinants were measured using the scale developed by Busenitz et al. (2000). By contrast, questionnaire items pertaining to perceived desirability and feasibility were adapted from other previous studies (Busenitz et al., 2000; Krueger et al., 2000). The 265 Estonian students were from different degree courses such as business management, medicine, engineering, and humanities. Of the respondents, $44.2 \%$ were determined to be aged $18-20$ years, $53.2 \%$ were determined to be female, and more than $70.9 \%$ were determined to be studying for their bachelor's degrees. Finally, students were asked to identify themselves as business or non-business students to further examine the differences in business and non-business school students' perceptions of institutional environment, entrepreneurship (desirability and feasibility), and entrepreneurial intentions by using independent samples t-test analysis.

\section{Analytical Approach}

The initial step in our analysis was to examine the relationships between constructs. Hence, we first assessed Pearson's correlation coefficients (Table 1). We examined Cronbach alpha values, the Kaiser-Meyer-Olkin (KMO) and Bartlett tests, average variance extracted ( $A V E$ ), and composite reliability $(C R)$ to determine the validity of the items in each construct. Subsequently, we tested the hypotheses and model fit using structural equation modelling (Arbuckle, 2006) and confirmatory factor analysis through Amos. Confirmatory factor analysis has frequently been used to assess construct validity in structural equation modelling (Jöreskog, 1969). All constructs were tested to assess scale validity, and the results are listed in Table 2.

In Table 1, the results obtained from Pearson's correlation analysis indicate that the variables in our study are significantly correlated. Therefore, we included all variables in our subsequent analyses.

Table 2 presents the scale assessment results, indicating the confirmatory factor analysis (CFA), Cronbach alpha, KMO and Bartlett test, AVE, and CR values used to evaluate scale validity. Factor loadings observed for all items are above the 0.4 cut-off (Nunnally, 
Table 1. Variables correlation using Pearson's correlation analysis $(n=265)$

\begin{tabular}{|l|c|c|c|c|c|c|}
\hline \multicolumn{1}{|c|}{ Constructs } & $\mathbf{1}$ & $\mathbf{2}$ & $\mathbf{3}$ & $\mathbf{4}$ & $\mathbf{5}$ & $\mathbf{6}$ \\
\hline Regulatory & 1 & & & & & \\
\hline Normative & $0.830^{* *}$ & 1 & & & & \\
\hline Cognitive & $0.829^{* *}$ & $0.868^{* *}$ & 1 & & & \\
\hline Desirability & $0.731^{* *}$ & $0.790^{* *}$ & $0.770^{* *}$ & 1 & & \\
\hline Feasibility & $0.756^{* *}$ & $0.817^{* *}$ & $0.815^{* *}$ & $0.876^{* *}$ & 1 & \\
\hline Entrepreneurial intention & $0.746^{* *}$ & $0.790^{* *}$ & $0.777^{* *}$ & $0.868^{* *}$ & $0.886^{* *}$ & 1 \\
\hline Mean & 4.16 & 4.22 & 4.18 & 4.23 & 4.20 & 4.19 \\
\hline Standard Deviation & 0.827 & 0.861 & 0.882 & 0.821 & 0.833 & 0.877 \\
\hline
\end{tabular}

Significant codes: ${ }^{* *}$ Correlation is significant at the 0.01 level (2-tailed)

Source: own calculations in SPSS.

Table 2. Scale assessment results $(n=265)$

\begin{tabular}{|c|c|c|c|c|c|c|}
\hline Constructs & Items & Factors Loading & $\alpha$ & KMO & AVE & C.R. \\
\hline $\begin{array}{l}\text { 1. Regulatory Institutional Environ- } \\
\text { ment }\end{array}$ & $\begin{array}{l}\text { REG1 } \\
\text { REG2 } \\
\text { REG3 } \\
\text { REG4 } \\
\text { REG5 }\end{array}$ & $\begin{array}{l}0.82 \\
0.79 \\
0.79 \\
0.82 \\
0.86\end{array}$ & 0.91 & 0.88 & 0.67 & 0.92 \\
\hline $\begin{array}{l}\text { 2. Normative Institutional Environ- } \\
\text { ment }\end{array}$ & $\begin{array}{l}\text { NOR1 } \\
\text { NOR2 } \\
\text { NOR3 } \\
\text { NOR4 } \\
\text { NOR5 }\end{array}$ & $\begin{array}{l}0.82 \\
0.78 \\
0.84 \\
0.81 \\
0.89\end{array}$ & 0.92 & 0.89 & 0.64 & 0.90 \\
\hline $\begin{array}{l}\text { 3. Cognitive Institutional Environ- } \\
\text { ment }\end{array}$ & $\begin{array}{l}\text { COG1 } \\
\text { COG2 } \\
\text { COG3 } \\
\text { COG4 }\end{array}$ & $\begin{array}{l}0.86 \\
0.84 \\
0.86 \\
0.83\end{array}$ & 0.91 & 0.83 & 0.71 & 0.91 \\
\hline 4. Perceived Desirability & $\begin{array}{l}\text { DEA1 } \\
\text { DEA2 } \\
\text { DEA3 } \\
\text { DEA4 } \\
\text { DEA5 }\end{array}$ & $\begin{array}{l}0.90 \\
0.81 \\
0.76 \\
0.82 \\
0.81\end{array}$ & 0.91 & 0.88 & 0.66 & 0.91 \\
\hline 5. Perceived Feasibility & $\begin{array}{l}\text { FEA1 } \\
\text { FEA2 } \\
\text { FEA3 } \\
\text { FEA4 } \\
\text { FEA5 }\end{array}$ & $\begin{array}{l}0.91 \\
0.83 \\
0.81 \\
0.80 \\
0.87\end{array}$ & 0.93 & 0.89 & 0.72 & 0.93 \\
\hline 6. Entrepreneurial Intention & $\begin{array}{l}\text { EI1 } \\
\text { EI2 } \\
\text { EI3 } \\
\text { EI4 }\end{array}$ & $\begin{array}{l}0.85 \\
0.83 \\
0.83 \\
0.89\end{array}$ & 0.92 & 0.85 & 0.73 & 0.91 \\
\hline
\end{tabular}

Source: Busenitz, Gomez, and Spencer (2000) and Ajzen (1991).

1978). Moreover, the Cronbach alpha values are above 0.7 . These values comply with the minimum acceptable level suggested by Nunnally (1978), thus confirming scale validity. 
Similarly, the KMO and Bartlett test values are above the 0.50 cut-off, which represents an acceptable level (Gerbing \& Anderson, 1988).

According to the criteria suggested by Fornell-Larcker (1981), the AVE and CR can be used to calculate the convergent validity of a model. The AVE measures the level of variance captured by a construct versus the level of variance due to measurement errors. Accordingly, we applied these measures to assess the degree of shared variance between the latent variables of the model. As presented in Table 2, the AVE values are above the 0.5 cut-off, which is acceptable. Moreover, the CR values are above 0.7 , which is also considered acceptable. Therefore, the institutional environment items are valid in European countries such as Estonia.

\section{RESULTS AND DISCUSSION}

Structural equation modelling (SEM) was used to examine the hypotheses and the fit between the implied structural model and empirical data. Table 3 lists the results.

Table 3. Structural equation modelling results $(n=265)$

\begin{tabular}{|l|c|c|c|l|}
\hline \multicolumn{1}{|c|}{ Causal relationship } & $\boldsymbol{\beta}$ & t-value $^{\mathbf{a}}$ & p-value & \multicolumn{1}{|c|}{ Hypothesis } \\
\hline Regulatory environment - Desirability & 1.97 & 3.77 & $* * *$ & H1a: Supported \\
Normative environment - Desirability & 1.77 & 3.42 & $* * *$ & H1b: Supported \\
Cognitive environment - Desirability & 1.00 & 1.81 & 0.071 & H1c: Not Supported \\
Regulatory environment - Feasibility & 1.85 & 3.57 & $* * *$ & H2a: Supported \\
Normative environment - Feasibility & 1.49 & 2.68 & $0.007^{* *}$ & H2b: Supported \\
Cognitive environment - Feasibility & 1.23 & 2.45 & $0.014^{*}$ & H2c: Supported \\
Desirability - Entrepreneurial intention & 0.208 & 2.17 & $0.030^{*}$ & H3: Supported \\
Feasibility - Entrepreneurial intention & 0.772 & 7.63 & $* * *$ & H4: Supported \\
\hline
\end{tabular}

Note: $\mathrm{GFI}=0.885 ; \mathrm{CFI}=0.975 ; \mathrm{IFI}=0.976 ; \mathrm{RMSEA}=0.047 ; \mathrm{CMIN} / \mathrm{df}=1.585$

${ }^{a} t$-value $>1.96$ for $p<0.05$ and $>2.33$ for $p<0.01$ (Kline, 1998)

Significant codes: ${ }^{* * *} p<0.001,{ }^{* *} p<0.01,{ }^{*} p<0.05$

Source: Based on own research conducted in 2019.

Table 3 reveals that regulatory and cognitive institutional environments have a positive relationship with entrepreneurial intention through perceived desirability, so $\mathrm{H} 1 \mathrm{a}$ and $\mathrm{H} 1 \mathrm{c}$ are supported ( $\mathrm{H} 1 \mathrm{a}: \beta=1.97, p<0.001 ; \mathrm{H} 1 \mathrm{c}: \beta=1.77, p<0.001)$. However, the results reveal no positive relationship between a cognitive institutional environment and entrepreneurial intention through perceived desirability, so $H 1 b$ is not supported $(H 1 b: \beta=1.00$, n.s.). Furthermore, the three dimensions of institutional environment (regulatory, normative, and cognitive) are significantly related to entrepreneurial intention through perceived feasibility, so $\mathrm{H} 2 \mathrm{a}, \mathrm{H} 2 \mathrm{~b}$, and $\mathrm{H} 2 \mathrm{c}$ are supported $(\mathrm{H} 2 \mathrm{a}: \beta=1.85, p<0.001 ; \mathrm{H} 2 \mathrm{~b}$ : $\beta=1.23, p<0.05 ; \mathrm{H} 2 \mathrm{c}: \beta=1.49, p<0.01$ ). Moreover, the results indicate positive effects of perceived desirability and perceived feasibility on entrepreneurial intentions, which supports $\mathrm{H} 3$ and $\mathrm{H} 4$ (H3: $\beta=0.208, p<0.05 ; \mathrm{H} 4: \beta=0.772, p<0.001)$.

The institutional theory provides a useful perspective for explaining why entrepreneurs in some countries are more active and competitive than their counterparts in other countries and why some cities may become strongholds of entrepreneurship that attract investors, entrepreneurs, and talent from all over the world (Busenitz et al., 2000). Fayolle and Francisco (2014) suggest that regulatory, normative, and cognitive 
institutional environments can both constrain and promote individuals' perceived desirability and feasibility of entrepreneurship. Notably, prior research has generated inconsistent findings on the relationship between the institutional environment and individuals' perceived desirability and feasibility.

A growing body of research - conducted mostly in developed economies - widely acknowledges the pivotal role of bureaucratic systems, social norms, and entrepreneurial cognition in individuals' entrepreneurial motivation (Heilbrunn et al., 2017; Stenholm, Acs, \& Wuebker, 2013; Veciana \& Urbano, 2008). By contrast, studies conducted in developing economies make different discoveries. For example, Urban and Kujinga (2017) investigated college students' entrepreneurship in South Africa to determine that only the regulatory environment has a positive impact on perceived feasibility and desirability. Similarly, an empirical study conducted in Thailand suggests that the institutional environment (i.e. government regulation, social norms, and people's entrepreneurial cognition) has a positive influence only on perceived feasibility and not on perceived desirability (Wannamakok \& Chang, 2020).

In the present study, we used a unique sample from Estonia in an attempt to reconcile this inconsistency in the literature. Our results indicate that - in the Estonian context - a favourable institutional environment may generally motivate people to engage in new venture initiatives by reinforcing their positive perceptions of entrepreneurial processes. In addition, our results suggest that the cognitive environment is the only dimension that does not exert a significant effect on Estonian university students' perceived desirability of an entrepreneurial career. Culture may explain the differences in findings between our study and the Thai study (Wannamakok \& Chang, 2020). Although collectivism and shortterm orientation in Thailand's national culture make institutional systems effective in boosting people's perceived feasibility, they cannot easily arouse their perceived desirability for entrepreneurship. By contrast, Estonia is a country characterised by high levels of long-term orientation and individualism (Hofstede Insights, 2020). The findings of this study imply that national institutions play a more critical role in citizens' entrepreneurship in countries where the culture is high in individualism and long-term orientation. Echoing prior research (Welter \& Smallbone, 2011), our findings not only highlight the complicated role of national culture in the institution entrepreneurship nexus but reflect the need for a cross-cultural investigation to yield more context-dependent results.

This study was conducted using data gathered from a survey of Estonian university students. Because of the disparity in the ease of job hunting, students from different majors may have diverse perceptions of the institutional environment and their career aspirations. Entrepreneurship and new venture management are common courses in most business schools. Therefore, through an independent samples t-test, we examined the differences in students' perceptions of institutional environment, entrepreneurship (desirability and feasibility), and entrepreneurial intentions between business and non-business school students. The results are listed in Table 4.

According to Table 4, the results of the t-test suggest that significant differences exist in the perceptions of normative and cognitive environments, perceptions of desirability, perceptions of feasibility, and entrepreneurial intentions between business and non-business school students. Students from business schools have higher scores in these factors than students from other disciplines. As observed by Grassl and Jones 
(2005), business students have more opportunities to learn about entrepreneurship and experience new venture activities. These findings are consistent with those of a previous study that revealed that non-business school students are likely to have lower levels of entrepreneurial intention (Doe, 2017). Thus, although the institutional environment is essential in determining entrepreneurial intentions, its degree of importance may vary depending on the individuals' profession and specialty.

Table 4. Independent samples t-test result (Academic Major)

\begin{tabular}{|l|c|c|c|c|c|c|c|}
\hline \multicolumn{1}{|c|}{ Sample groups } & \multicolumn{2}{c|}{ Business (N=122) } & \multicolumn{5}{c|}{ Non-Business (N=143) } \\
\hline \multicolumn{1}{|c|}{ Construct } & M & S.D. & M & S.D. & T & P-value & Df \\
\hline Regulatory environment (REG) & 4.240 & 0.708 & 4.107 & 0.903 & 1.303 & 0.194 & 261 \\
Normative environment (NOR) & 4.345 & 0.746 & 4.127 & 0.934 & 2.099 & $0.037^{*}$ & 261 \\
Cognitive environment (COG) & 4.314 & 0.780 & 4.090 & 0.937 & 2.111 & $0.036^{*}$ & 261 \\
Perceived Desirability (DEA) & 4.393 & 0.687 & 4.092 & 0.900 & 3.070 & $0.002^{* *}$ & 261 \\
Perceived Feasibility (FEA) & 4.365 & 0.699 & 4.092 & 0.897 & 2.766 & $0.006^{* *}$ & 261 \\
Entrepreneurial intention (EI) & 4.320 & 0.765 & 4.111 & 0.922 & 2.007 & $0.046^{*}$ & 261 \\
\hline
\end{tabular}

Significant codes: ${ }^{* *} p<0.01,{ }^{*} p<0.05$

Source: based on own research conducted in 2019.

\section{CONCLUSIONS}

The relationship between a nation's institutional environment and its citizens' entrepreneurship has been extensively tested in different cultural contexts, but the findings remain inconclusive (Klapper \& Love, 2010). This study adds to the literature on the relationship between national institutions and entrepreneurial intentions. From the Estonian perspective, our results contribute to the growing body of knowledge about how governments may facilitate entrepreneurship by cultivating an institutional environment, in which regulations, norms, and public cognition favour individuals' entrepreneurial initiatives. For policymakers in Eastern Europe or the Baltic regions, the findings of this study may provide useful guidance on establishing an entrepreneurship-munificent environment to boost the prosperity of small businesses and spur economic growth. According to the path analysis results, institutional environment dimensions may help explain individuals' entrepreneurial intentions by affecting their perceived desirability and feasibility (Boris, 2013). This study indicates the profound impacts of institutional systems on university students' entrepreneurial intentions in Estonia. Due to the unique research context, our findings may serve as a springboard for future investigative efforts regarding entrepreneurial intentions in Eastern European or Baltic countries such as Estonia, Latvia, and Lithuania.

Our findings also have policy and practical implications. Stimulating entrepreneurship is an effective strategy to minimise unemployment rates and facilitate economic growth (Castaño, Méndez, \& Galindo, 2016). To achieve this goal, a country's government may seek to develop an entrepreneurial ecosystem that promotes start-up establishment, encourages a pro-entrepreneurial financial system, and fosters entrepreneurial training and education. When citizens are exposed to an environment full of entrepreneurial spirit, they are more likely to acquire knowledge about running a new business and enthusiasm for a self-employed career. Moreover, government bureaucracy is a common hindrance to new venture creation. Reducing unnecessary administrative procedures may increase 
the ease of founding and running a start-up firm. In particular, a supportive and efficient regulatory environment may enable entrepreneurs to focus on the issues that truly matter to the core values of their start-up firms instead of satisfying performance goals that do not pertain to the growth of their new venture.

Our study has four limitations. Firstly, our sample includes only 265 Estonian students, constraining its representativeness. Secondly, the survey was administered through the Internet, making it challenging to verify the identities of the respondents. Thirdly, the use of self-report questionnaires may lead to the threat of common method bias. Future research may adopt a longitudinal design to observe actual entrepreneurial behaviour to investigate the causal relationship between institutional environment, perceptions, and entrepreneurship. Moreover, we encourage future work to explore how individuals' demographic characteristics affect the way they perceive their institutional environment and develop entrepreneurial motivation. Finally, although our use of the unique Estonian sample is valuable for understanding individuals' entrepreneurship in a Baltic context, our findings may have low generalisability to countries with different cultures.

\section{REFERENCES}

Ajzen, I. (1991). The theory of planned behavior. Organizational Behavior and Human Decision Processes, 50(2), 179-211.

Anderson, J.C., \& Gerbing, D.W. (1988). Structural equation modeling in practice: A review and recommended two step approach. Psychological Bulletin, 103(3), 411.

Arbuckle, J.L. (2006). AMOS 7 User's Guide. Chicago: SPSS.

Bernardino, S., Santos, J.F., \& Ribeiro, J.C. (2016). Social entrepreneurship: Does institutional environment make a difference?. In Handbook of Research on Entrepreneurial Success and its Impact on Regional Development (pp. 513-538). IGI Global.

Bruno, A.V., \& Tyebjee, T.T. (1982). The environment for entrepreneurship. Encyclopedia of Entrepreneurship, 2(4), 288-315.

Brush, C.G., Duhaime, I.M., Gartner, W.B., Stewart, A., Katz, J.A., Hitt, M.A., Alvarez, S.A., Meyer, G.D., \& Venkataraman, S. (2003). Doctoral education in the field of entrepreneurship. Journal of Management, 29(3), 309331.

Bruton, G.D., Ahlstrom, D., \& Li, H.L., (2010). Institutional theory and entrepreneurship: Where are we now and where do we need to move in the future?. Entrepreneurship: Theory and Practice, 34(3), 421-440

Busenitz, L.W., \& Barney, J.B. (1997). Differences between entrepreneurs and managers in large organizations: Biases and heuristics in strategic decision-making. Journal of Business Venturing, 12(1), 9-30.

Busenitz, L.W., Gomez, C., \& Spencer, J.W. (2000). Country institutional profiles: Unlocking entrepreneurial phenomena. Academy of Management Journal, 43(5), 994-1003.

Díaz-Casero, J.C., Ferreira, J.J.M., Hernández Mogollón, R., \& Barata Raposo, M.L. (2009). Influence of institutional environment on entrepreneurial intention: a comparative study of two countries university students. International Entrepreneurship and Management Journal, 8(1), 55-74.

Castaño, M.S., Méndez, M.T., \& Galindo, M.Á. (2016). The effect of public policies on entrepreneurial activity and economic growth. Journal of Business Research, 69(11), 5280-5285.

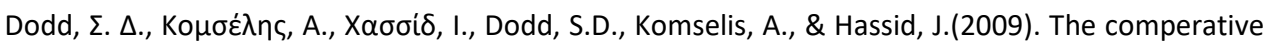
perceived desirability and feasibility of entrepreneurship within Greek schools. SPOUDAl-Journal of Economics and Business, 59(1-2), 38-56. 
Doe, R. (2017). Entrepreneurship among Non-Business Students: Implications for Entrepreneurship Education. American Journal of Management, 17(7), 24-32.

Dutta, S., Geiger, T., \& Lanvin, B. (2015). The Global Information Technology (Report 2015: ICTs for Inclusive Growth). Geneva, World Economic Forum.

Entrialgo, M., \& Iglesias, V. (2016). The moderating role of entrepreneurship education on the antecedents of entrepreneurial intention. International Entrepreneurship and Management Journal, 12(4), 1209-1232.

Fayolle, A., \& Liñán, F. (2014). The future of research on entrepreneurial intentions. Journal of Business Research, 67(5), 663-666.

Fornell, C., \& Larcker, D.F. (1981). Structural equation models with unobservable variables and measurement error: Algebra and statistics. Journal of Marketing Research, 18 (3), 328-388.

Franco, M., \& Haase, H. (2019). Sustainable Development of Small and Medium-Sized Enterprises in Disadvantaged Regions: Impact of Knowledge and Innovation. In Knowledge, Innovation and Sustainable Development in Organizations (pp. 39-59). Cham: Springer.

GEM (2015). GEM 2014 Global Report. Retrieved from http://gemconsortium.org/report on October $12,2018$.

Grassl, W., \& Jones, J. (2005). Entrepreneurial intent among students: Are business undergraduates different?. St. Norbert College, USA. Retrieved from https://www.snc.edu on October 20, 2018.

Heilbrunn, S., Itzkovitch, Y., \& Weinberg, C. (2017). Perceived feasibility and desirability of entrepreneurship in institutional contexts in transition. Entrepreneurship Research Journal, 7(4), 785-796.

Hofstede Insights (2020). Compare countries. Retrieved from https://www.hofstede-insights.com/ on April 15, 2020.

Jennings, P.D., Greenwood, R., Lounsbury, M.D., \& Suddaby, R., (2013). Institutions, entrepreneurs, and communities: A special issue on entrepreneurship. Journal of Business Venturing, 28(1), 1-9.

Jöreskog, K.G. (1969). A general approach to confirmatory maximum likelihood factor analysis. Psychometrika, 34(2), 183-202.

Katz, J.A. (2003). The chronology and intellectual trajectory of American entrepreneurship education 1876-1999. Journal of Business Venturing, 18(2), 283-300.

Klapper, L., \& Love, I. (2010). The impact of business environment reforms on new firm registration. The World Bank.

Kline, R.B. (1998). Principles and Practice of Structural Equation Modelling. Montreal: The Guilford Press.

Krueger Jr, N.F., \& Brazeal, D.V. (1994). Entrepreneurial potential and potential entrepreneurs. Entrepreneurship Theory and Practice, 18(3), 91-104.

Krueger Jr, N.F., Reilly, M.D., \& Carsrud, A.L. (2000). Competing models of entrepreneurial intentions. Journal of Business Venturing, 15(5-6), 411-432.

Lourenço, F., Sappleton, N., \& Cheng, R. (2015). Gender and business ethics of enterprise students and nascent entrepreneurs engaged in entrepreneurship education. The Journal of Entrepreneurship, 24(2), 186-203

Manolova, T.S., Eunni, R.V., \& Gyoshev, B.S. (2008). Institutional environments for entrepreneurship: Evidence from emerging economies in Eastern Europe. Entrepreneurship Theory and Practice, 32(1), 203-218.

Melin, K. (2002). The Entrepreneurial Intentions and Their Background in Estonia and Finland - A Comparative Study in Selected Vocational Schools. Europa Liiduga liitumise $m^{\sim}$ oju Eesti majanduspoliitikale, 529-536. 
Michoń, P. (2019). The Baltic miracle? The economic crisis and its consequences for young people in the labor market of the Baltic states, 2007-2017. Journal of Baltic Studies, 50(1), 7-20.

Minniti, M. (2008). The role of government policy on entrepreneurial activity: productive, unproductive, or destructive?. Entrepreneurship Theory and Practice, 32(5), 779-790.

Murphy, M., \& Dyrenfurth, M. (2019). The Expanding Business of the Entrepreneurial University: Job Creation. In The Engineering-Business Nexus (pp. 207-230). Cham: Springer.

Mursa, G.C., lacobuta, A.O., Socoliuc, O.R., Clipa, R.I., \& Butiseaca, A. (2018). Youth Unemployment among EU Countries - A Challenge for Sustainable Growth and Social Cohesion. Transformations in Business \& Economics, 17, 701-720.

Nunnally, J.C. (1978). Psychometric Theory (2nd ed). New York, NY: McGraw-Hill.

OECD (2018). OECD Employment Outlook 2017. Paris: OECD.

SBA (Small Business Act for Europe) (2017). SBA Fact Sheet: Estonia (Brussels: European Commission).

SBA (Small Business Act for Europe) (2018). SBA Fact Sheet: Estonia (Brussels: European Commission).

Scott, R. (1995). Institutions and organizations. Thousand Oaks, CA: Sage.

Shane, S.A. (2003). A general theory of entrepreneurship: The individual-opportunity nexus. Edward Elgar Publishing.

Shane, S.A. (2008). The illusions of entrepreneurship: The costly myths that entrepreneurs, investors, and policy makers live by. Yale University Press.

Shane, S., Locke, E.A., \& Collins, C.J. (2003), Entrepreneurial motivation. Human Resource Management Review, 13, 257-279.

Shapero, A., \& Sokol, L. (1982). The social dimensions of entrepreneurship. Encyclopedia of Entrepreneurship, 72-90.

Shneor, R., Jenssen, J. I., \& Vissak, T. (2016). Current challenges and future prospects of Entrepreneurship in Nordic and Baltic Europe. Baltic Journal of Management, 11(2), 134-141.

Urban, B. (2008). Social entrepreneurship in South Africa: delineating the construct with associated skills. International Journal of Entrepreneurial Behaviour and Research, 14(5), 46-364.

Urban, B. (2013). Influence of the institutional environment on entrepreneurial intentions in an emerging economy. The International Journal of Entrepreneurship and Inno-vation, 14(3), 179-191.

Urban, B., \& Kujinga, L. (2017). The institutional environment and social entrepreneurship intentions. International Journal of Entrepreneurial Behavior \& Research, 23(4), 638-655.

Vaillant, Y., \& Lafuente, E. (2007). Do different institutional frameworks condition the influence of local fear of failure and entrepreneurial examples over entrepreneurial activity?. Entrepreneurship and Regional Development, 19(4), 313-337.

Veciana, J.M., Aponte, M., \& Urbano, D. (2002). Institutions and support programmes for entrepreneurship: a two countries comparison. Proceedings, International Council for Small Business, Puerto Rico (2002).

Veciana, J.M., \& Urbano, D. (2008). The institutional approach to entrepreneurship research. Introduction. International Entrepreneurship and Management Journal, 4(4), 365-379.

Wannamakok, W., \& Chang, Y.Y. (2020). Institutional Environments and Social Entrepreneurial Intentions: A Case of Thailand. Review of Integrative Business and Economics Research, 9(1), 97-111.

Welter, F., \& Smallbone, D. (2011). Institutional perspectives on entrepreneurial behavior in challenging environments. Journal of Small Business Management, 49(1), 107-125.

Whitley, R. (1999). Divergent capitalism: The social structuring and change of business systems. New York: Oxford University Press. 


\section{Appendix A: Items constituting}

\section{Regulatory environment / Õigusruum}

1. Government organisations assist individuals starting their own businesses /

Riigiasutused abistavad ettevõtlusega alustavaid inimesi.

2. Government sets aside government contracts for new and small businesses /

Riik sõlmib uute ja alustavate ettevõtetega riiklike tellimuste täitmiseks lepinguid.

3. Local and national government have special support for individuals starting a new business / Kohalik omavalitsus ja riik pakuvad inimestele ettevõtlusega alustamiseks toetust.

4. Government sponsors organisations that help new businesses develop /

Riiklik rahastab organisatsioone, mis toetavad uute ettevõtete arengut.

5. Even after failing, government assists entrepreneurs starting again /

Riik aitab ettevõtjatel isegi pärast ebaõnnestumist uuesti alustada.

\section{Normative environment / Väärtusruum}

1. Turning new ideas into businesses is admired in this country / selles riigis väärtustatakse uute ideede elluviimist ettevõtlustegevuses.

2. Innovative and creative thinking is viewed as a route to success in Estonia /

Eestis peetakse uuenduslikku ja loovat mõtlemist edu pandiks.

3. Entrepreneurs are admired in this country / Selles riigis peetakse ettevõtjatest lugu.

4. People in Estonia greatly admire those who start their own businesses /

Eesti inimesed imetlevad neid, kes alustavad oma ettevõttega.

\section{Cognitive environment / Kognitiivne, ehk tunnetuslik keskkond}

1. Individuals know how to protect a new business legally /

Inimesed teavad, kuidas uut ettevõtet õiguslikult kaitsta.

2.Those who start new businesses know how to deal with risk /

Uue ettevõttega alustajad teavad, kuidas riskiga toime tulla.

3. Those who start new businesses know how to manage risk /

Uue ettevõttega alustajad teavad, kuidas riske juhtida.

4. Most people know where to find info about markets for their products /

Enamik inimesi teab, kust leida infot oma toodete turgude kohta.

\section{Feasibility / Teostatavus}

1. I am ready to start a prospective business /

Ma olen valmis tulevikus ettevõtlusega alustama.

2. I can control the process of creating a new business firm /

Mul saan kontrollida uue ettevõtte asutamise protsessi.

3. I know the necessary practical details about starting a new business/firm /

Ma tean, millised on uue ettevõtte asutamiseks vajalikud praktilised üksikasjad.

4. I know how to develop my business if I have my own business/firm /

Kui mul on oma ettevõte, siis ma tean, kuidas seda arendada.

5. I have a high probability of success /

Mul on suur tõenäosus edu saavutada.

\section{Desirability / Kirg}

1. Being an entrepreneur implies more advantages than disadvantages to me /

Ettevõtja staatusel on minu jaoks rohkem eelised kui puudusi.

2. An entrepreneurial career is interesting to me /

Ettevõtja karjäär huvitab mind. 
3. If I had opportunities, capital and abilities, I will start a new business /

Kui mul oleks võimalusi, kapitali ja võimeid, asutaksin ettevõtte.

4. Being an entrepreneur will give me enormous satisfaction /

Ettevõtlusega tegelemine pakub mulle tohutut rahuldust.

5. Among various options, I would rather be an entrepreneur /

Eri võimalusi kaaludes eelistaksin olla ettevõtja.

6. Entrepreneurial Intentions / Ettevõtluskavatsused

1. I am thinking to be an entrepreneur in the future /

Ma soovin tulevikus ettevõtjaks saada.

2. I have very seriously thought of starting a business in the future /

Ma olen väga tõsiselt mõelnud oma ettevõtte loomisele.

3. I have a strong intention to start a business in the future /

Mul on kindlasti kavas tulevikus oma ettevõte luua.

4. I am ready to do anything to be an entrepreneur /

Ma olen kõigeks valmis, et ettevõtjaks saada. 


\section{Authors}

The contribution share of authors is equal and amounted to $1 / 3$ for each of them.

\section{Wisuwat Wannamakok}

His current research focuses on entrepreneurship, social innovation, and education. He has published papers listed in Gender in Management, Journal of Entrepreneurship, Business and Economics, Review of Integrative Business, and Economics Research, etc.

Correspondence to: Wisuwat Wannamakok, Southern Taiwan University of Science and Technology, No. 1, Nan-Tai Street, Yongkang Dist., Tainan City 710, Taiwan, e-mail: da61g203@stust.edu.tw ORCID (1) http://orcid.org/0000-0002-2332-9592

\section{Yu-Yu Chang}

Assistant Professor at National Cheng Kung University, Taiwan. Dr Chang earned his doctoral degree at the Graduate Institute of Technology Management, National Chung Hsing University, Taiwan. His current research focuses on entrepreneurship, social capital, and creativity. He has published papers in Technological Forecasting and Social Change, Journal of Business Research, Creativity and Innovation Management Journal, Entrepreneurship Research Journal, International Journal of Entrepreneurial Behavior \& Research, International Entrepreneurship and Management Journal, Human Resource Management Review, etc.

Correspondence to: Yu-Yu Chang, National Cheng Kung University, No.1, University Road, Tainan City 701, Taiwan, e-mail: yychang@gs.ncku.edu.tw ORCID (1) http://orcid.org/0000-0003-2458-0567

\section{Marge Täks}

Head of the Department of Management at Estonian Business School. She received a PhD in educational sciences at the University of Tartu. Her research mainly revolves around entrepreneurship teaching but also focuses on learning and teaching in a more general setting. She has published papers in Journal of Engineering Education, Journal of the Humanities \& Social Sciences, Education Research International, European Journal of Engineering Education, etc.

Correspondence to: Marge Täks, department of Management at Estonian Business School, Tallinn, Estonia, e-mail: marge.taks@ebs.ee

ORCID (1) http://orcid.org/0000-0001-8370-6751

\section{Acknowledgements and Financial Disclosure}

The authors would like to thank the Ministry of Science and Technology of Taiwan for funding this project with the Young Scholar Fellowship Program (MOST 109-2636-H-006-001), the Dora Plus from the Estonian government programme for studying and research, and the Business and Management PhD Program of Southern Taiwan University of Science and Technology, Taiwan.

\section{Copyright and License}



This article is published under the terms of the Creative Commons Attribution - NoDerivs (CC BY-ND 4.0) License http://creativecommons.org/licenses/by-nd/4.0/ 